\title{
New Concept of Property Right on Land: From the View Point of Sustainability
}

\author{
Yoshiki Kurumisawa \\ WASEDA University, Faculty of Law \\ Tokyo, JAPAN
}

\begin{abstract}
The great transformation from industrial to sustainable society is one of the most important challenges today. 'Sustainability' is a key concept to constitute the society of the 21 st century. The modern legal system, which has operated as an infrastructure of industrial society, must adapt itself to the transformation. In the following I shall consider the new function and content of property rights on agricultural land in Japan which can promote sustainable agriculture. The transformation from industrial to sustainable society cannot be realised in a nation-state. Without a common Asian legal perspective like EU Law, we could not have a view of sustainable Asian society. We need now a new method of comparative law, namely comparative 'Law and Society'. A key concept would be "universality and context of law".
\end{abstract}

Keywords-Sustainability, Property right on agricultural land, Cultivator-based principle, Universality and context of law

\section{LAW AND SUSTAINABILITY}

\section{A. The Concept of Sustainability}

According to the Flagship Report 2011 of the German Advisory Council on Global Change, ${ }^{1}$ human beings experienced three great transformations; the first one was the wide-scale transition from a lifestyle of hunting and gathering to that of agriculture and settlement; the second one was the transition from agricultural to industrial society; and we are now confronted with the third great transformation: from industrial to sustainable society.

While both former transformations had progressed for a long period as natural processes, the third one could be realised only by intentional human activities, not through a natural process automatically. It would be a trial-and-error process which should be carried out consciously on a precautionary and provisionary basis, not as an immediate reaction to actual issues that can be experienced directly.

The concept of sustainability is an ambiguous, equivocal one to which any interpretation can be given. So we need a precise concept. However, that is not an aim of this paper, except to note that we understand the concept of sustainability to be a principle with which a whole society should be reconstituted through adjusting three structural elements of society, namely, welfare, ecology, and economy, under low economic growth. Sustainable society is an alternative to the welfare state (big government) and neo-liberal market society (small government), both of which have aimed their policy towards illusionary economic growth. ${ }^{2}$

\section{B. Two Different Approaches}

Now we must consider which role legal studies can/must play in the transformation. I think there are two different approaches.

One is to establish the 'sustainable principle' as a legal principle, like the 'precautionary principle' or 'polluter pays principle' in environmental law.

Some European Treaties such as the Treaty on European Union $^{3}$ or Charter of Fundamental Rights of The European Union ${ }^{4}$ have introduced the principle of sustainability, which has a direct binding force on the EU organisations and an indirect one on the member nations.

The other approach is to reconsider and reconstruct fundamental legal categories of modern law, for example, legal personhood, contract, property rights, etc., which have supported industrial society as its legal infrastructure. This approach should be the subject of the paper. I will deal with the case of property rights to land.

\section{PRIVATE PROPERTY RIGHTS RECONSIDERED}

\section{A. Abstract Character of Property Rights in Modern Concept}

The concept of private property rights in modern law is constructed as an idealistic, abstract, absolute, and exclusive right of a subject to a commodity. In capitalism, most objects of private property are commodity and capital. A right to a commodity means in the strict sense the right to an abstract exchange value inherent in a commodity, which we can recognise not with the five senses, but only conceptually. Therefore, the abstract concept of a property right to a commodity reflects the abstract character of exchange value. The property right to land as well, since it has been exchanged as a commodity, has acquired an abstract character. An owner of land can 
use it not necessarily directly by himself, but lease, dispose, or mortgage it. In order to get high interest, a person may buy land on speculation. Economic and financial crisis in economic globalisation is caused by financial trading (high-frequency trading (HFT)), originating in the abstract property right to capital, which is isolated from the real economy.

A private property right to land has functioned to cut off the concrete relationship between human beings and land (disposal right), which was the inevitable condition of abolishing the landlord system in feudal society and establishing a market system in which land can be freely exchanged. Property rights express an abstract relationship between subject (person) and object (land). They do not control the concrete relationship between them according to a certain context and space in which a person is situated and land is located. The abstract concept of property rights to land should be re-examined and reconstructed in the transformation to sustainable society.

\section{B. How Could the Property Rights be Reconstructed?}

The question here is how the property rights could be reconstructed.

Constitutions of liberal states protect property rights as fundamental human rights. 5

Therefore, an expropriation can be carried out only for the purpose of public welfare against fair compensation. On the other hand, the concrete content of property rights is to be decided by the legislator, who can change their content according to the changed economic order. Through legislation, we can create new property rights on each object adapting itself to the sustainable society. I would like to give two examples in the following section. The first example is the change of property rights to energy in Germany. The second one is the change of the content of property rights to agricultural land in Japan.

\section{CONCRETE EXAMPLES OF CHANGING THE CONTENT OF PROPERTY RIGHT}

\section{A. Change of Property Rights to Energy in Germany}

The German government has been implementing an energy shift from nuclear to renewable energy with a transition period of about 20 years since 2000. After this period, energy companies must shut down production according to the revised Nuclear Power Act, although they had been permitted to operate nuclear power plants without a term.

Is the ban on nuclear power generation a compulsory expropriation? If yes, the government should compensate operators for it according to the constitutional law. It would be an enormous amount of money. Some constitutional scholars insist that it must be a compulsory expropriation because the state deprives plant owners of a specific individual legal status to operate nuclear power plants. ${ }^{6}$ For other scholars, ${ }^{7}$ it is to the contrary not a deprivation of an individual private right, but a new prescription of the content of property rights by the revised act, a renewal of the content of property rights to nuclear production in general. The old content of property was abolished with a certain period of grace in which the investment in plant and equipment can be depreciated, so as not to be compensated.

The legislator has established the new property right to producing energy from renewable materials. I think we can see here a new concrete concept of property rights on energy products conforming itself to sustainable society.

I will give another example of the renewal of the content of private property rights for sustainable society.

B. Change of the Content of Property Rights on Agricultural Land in Japan

1) The Landlord System before the Second World War in Japan $^{8}$

In Japan, free transactions in agricultural land were fully allowed from the early years of the Meiji era on. The Meiji government lifted the ban on sales of land ownership and recognised the freedom of all classes of people to buy and sell agricultural land. Meanwhile, it also carried out reforms on land taxation; issued land certification (of land ownership) to the farmers, considering land taxpayers as land owners; and established the land-pricing system.

National finances at that time were strongly based on land taxes. Heavy land taxes were imposed on land owners. Small and medium-scale farmers could not support themselves under heavy taxes and devaluation of agricultural produce. They had no choice but to mortgage their farms to merchants or large farm operators for loans. Many farmers could not repay their loans and had to transfer their ownership in the mortgaged farms to the lenders. They became tenant farmers who cultivated a piece of land which had been theirs and had to pay rent to the landlord. In this way, a class structure began to develop in the rural areas, consisting of landlords who accumulated ownership in farmland that they acquired through mortgages from tenant farmers who lost their land. A parasitic landlord system was established. It continued until the agricultural land reforms at the end of the Second World War, therefore, took place as the system of modern land ownership was being established.

The landlord system was substantively different from the modern system of farm lease. The tenants had to pay an enormous amount of rent on more than half of the crops to the landlord. They were not rents comprehensible under a capitalist system, but more similar to those under the feudal regime. This landlord system that included personal domination over the tenants ought to be evaluated from the perspective of a pre-modern social relationship. Now the ownership by the landlord had become the title to exploit what tenant farmers produced.

\section{2) New Property Rights on Agricultural Land: Agricultural Land Act 1952}

Under post-war American occupation policies, agricultural land reform was carried out to dismantle the landlord system which had been the hotbed of fascism. The government then bought the land back from the landlords at a price that was nothing more than forced seizure and redistributed it to the tenants at a price as good 
as a free gift. As a result, small-scale self-reliant farmers who owned less than one hectare of agricultural land emerged on a wide scale.

Farmers' products no longer belonged to the landlord, but to farmers themselves.

According to this change, the content of ownership of agricultural land had been converted from the landlords' right to exploit the products of farmers to the productive right of farmers.

In 1953, the Agricultural Land Act was adopted in order to stabilise the achievements of agricultural land reforms and to prevent revival of the landlord system.

It was considered most appropriate for agricultural land to be owned by the cultivators themselves. Agricultural land transactions were to be subject to administrative permission, and acquisition of rights (by ownership or lease) with regard to agricultural land was to be confined to farmers.

In the light of Article 29 of the Constitution of Japan, we could understand that the legislator abolished the old property right of the landlord and provided the new content of property right on agricultural land.

This law has then been revised several times and remains applicable today not only to retain its important role in securing the availability of agricultural land, but also to support sustainable agriculture.

\section{CULTIVATORS-BASED PRINCIPLE IN THE AGRICULTURAL LAND LAW}

\section{A. Property right based on direct engagement in agriculture}

Our experience shows that as for farmland, it is necessary to start by recognising that holders of the right to farmland should be the people who have resided and engaged directly in farming there. The generally listed corporations cannot be allowed to become right-holders of agricultural land. The Japanese Agricultural Land Act adopts the legal principle that only natural persons who are not only managers but also directly engaged in agricultural cultivation or conceptually similar legal corporations working in agricultural production can become rightholders of agricultural land. This is called the 'cultivatorsbased principle'. The Farmers' Land Act (Bäuerliches Bodenrecht) in Switzerland and Agricultural Land Transaction Laws (Grundstückverkehrsgesetze) in Austria have a similar principle (Selbstbewirtschafterprinzip). These principles should have a universal validity, because they would provide an inevitable condition for sustainable agriculture.

Certainly when the Japanese Agricultural Land Act was first drafted in 1952, the legislative intent behind this principle was to prevent the return of the landlords who used to live parasitically on tenant farmers or the real producers. The fruits of labour were to belong to those who actually cultivated the land. The criticism that economic groups make today is that to apply such outdated provisions when the danger of revival of parasitic landlords has already passed is to create a barrier against engagement in agriculture, and blocks effective uses of agricultural land. They argue for abolishment of the Agricultural Land Act.

However, it is undeniable that the existence of agricultural land has been secured thanks to these provisions of the Agricultural Land Act that exclude nonagricultural operators by requiring strict factual review of whether or not those who acquired agricultural land actually engage themselves in agricultural activities. Since Japan does not have an integrated and powerful territorial planning and construction law system as exists in European countries, the Agricultural Land Act is taking on the task of saving agricultural land from development pressures. This is by no means an outdated function.

\section{B. Significance of the cultivator-based principle for sustainable agriculture \\ Nowadays, the need for flood prevention;} development of water resources; preservation of the natural environment, traditional landscapes, and cultures, etc., is known in general as resulting from agricultural production activities in rural areas (multiple functions of agriculture). The pre-condition for the agricultural sector to deliver its multiple functions sufficiently and appropriately in the future requires that conventional actors in agricultural production permanently reside in the local area, continue their production work, and unceasingly maintain the functions of the collectivity.

The Agricultural Land Act has contributed to the uninterrupted continuity of the relationship formed over the years between humans, on the one hand, who reside permanently in the local areas to carry out agricultural activities, and, on the other, the agricultural land as well as its surrounding natural resources (such as water and community properties, etc.). This contribution will continue into the future. We can, therefore, reconfirm the significance of the cultivator-based principle of the Agricultural Land Act in the current context.

Moreover, by making ownership and lease rights an intermediary in the relationship between the land as an object of labour and the farmers, the cultivator-based principle helps ensure a continuous relationship between the farmers and the land, and at the same time, demands unity between the main operators and their actual engagement in agricultural activities. Farmers not only engage themselves in agricultural activities, but also take on responsibility for operative decision-making, by mobilising different elements together, such as their own sensibility, feeling, and experiences in the changing climate, and the traditional techniques that they used in working the land. Under the cultivator-based principle, the three elements-land ownership, self-engagement in agricultural activities, and responsibility of managementare formed into one body, which gives birth to the inherent love for land and nurtures particularities in the agricultural products. This will lead to non-exploitative use of land as a means of production.

In contrast, listed corporations are typical forms of entities characterised by a clear separation among the shareholders, the managers, and the workers, or in other words, the separation of ownership, management, and 
labour. Corporations having offices in Tokyo try their best to acquire farmland in rural areas and employ local farmers as workers in order to develop agricultural operations. In this case, farmers are no longer managers. They are only expected to work in conformity with operative instructions sent from the headquarters in Tokyo to local offices through emails or phone calls. They are no longer concerned with, or responsible for, the kind of products or the resulting impact on the soil caused by operations done in conformity with these instructions. The overall unity that existed between them and the land in the former livelihood is lost. The relationship becomes incomplete, in a way similar to that between a wage-earner and his/her workplace.

\section{LIBERALIZATION AGAINST SUSTAINABILITY}

In Japan, arguments for the development of efficient and competitive entrepreneurial agricultural operations to cope with economic globalisation are gaining in importance day by day. Amendments to the Agricultural Land Act, which originally prohibited agricultural land acquisition by enterprises, have been submitted to the Diet for debate.

In June 2009, the Japanese government launched a legal amendment project to liberalise land lease in response to pressures from economic groups and demands by the neoliberal political forces and proposed amendments. The bill was passed in the Diet. The revision stipulates that everybody can lease agricultural land. This gives rise to concern that entities in charge of agricultural production will shift from local farmers to enterprises of overwhelming capital resources. Alternatively, there is a risk that the system of agricultural land management by farmers' groups will collapse as a result.

The Japanese government is now forced to renounce its food sovereignty and go in the opposite direction from realising self-sufficiency in foods and sustainable agriculture by participating in the Trans-Pacific Partnership (TPP), which provides for full trade liberalisation with no exceptions as a condition of participation. If the Japanese government would decide to abolish a tariff on rice, homestead farmers would become extinct, and the rate of self-sufficiency in food would fall below 14\%, which is a result of a test calculation announced by the Ministry of Agriculture, Forestry and Fisheries.

The government explained that this decline in food self-sufficiency might be avoided by improvement of agricultural structure, in other words, enlargement of a scale of management. For example, if a large company with competitive cost and large-scale agricultural management could enjoy economy of scale, the rate of self-sufficiency would rise.

The Agricultural Land Act prohibits a juridical person in general from purchasing agricultural land in order to keep it in the hands of homestead family farmers. This Act would be abolished, because the provision would be a serious obstacle to the intention of the government. Homestead family farmers will vanish from the Japanese countryside together with the traditional idyllic landscape. What will remain there?

My position is that we can realise sustainable agriculture only by protecting the existence of homestead farmers through maintaining the regulation of agricultural land transportation and establishing the new concept of property right on agricultural land.

If agriculture is evaluated only on the basis of it being a means of producing cheap agricultural goods, the multiple functions of family-based agricultural operators would be left out of sight. This would cause serious troubles. The way of setting up an agricultural land regime that meets the demand of contemporary society for economic sustainability should be to emphasise the retention of the existing Agricultural Land Act, which confers acquisition of rights over farm land only to those farmers who are directly engaged in agricultural cultivation.

\section{COMPARATIVE 'LAW AND SOCIETY' IN THE PERSPECTIVE FOR ASIAN REGIONAL LAW}

Thus, the globalised economy, which demands free trade as a universally valid principle, compels the nation-state to abolish its locality, which regulates the commodification of agricultural land. So, called land grabbing by foreign investors has developed in Asian countries under economic globalisation. Its inclination towards free deal in land has threatened the multifunction of agriculture which can be fulfilled only by homestead family farmers who knows well the bio circulation in their living area.

The transformation from industrial to sustainable society cannot be realised in a nation-state. At least, we should approach it step by step, namely, start the trial at a regional level, for us, in Asia.

Without a common Asian legal perspective like EU Law, we could not have a view of sustainable Asian society. For this stage, we should consider a new comparative legal methodology. Traditionally, we have used comparative law as a tool for reference when we codify our code or interpret codes. Now in the transformation from industrial to sustainable society, we must develop a new method of comparative law to codify sustainable regional law through harmonising and integrating laws in each Asian nation-state. The point at issue is the universality and context of law ${ }^{9}$. This point has been discussed in the context of legal assistance for socalled transformation countries after the dissolution of the Soviet Union. We must formulate law at the transnational level, we should not ignore the legal developments occurring at the level of respective nation-states.

This consideration is certainly useful for harmonising the legal systems in Asian countries and integrating them into the Asian regional law system.

What is required of comparative law scholars is to go beyond studying and comparing each country's substantive law and to employ a method for the sociology of comparative law, whereby relationships between law 
and society as a whole are compared on a country-bycountry basis.

1 German Advisory Council on Global Change: WBUG; World in Transition - A Social Contract for Sustainability, Flagship Report 2011

2 Hiroi, Yoshinori, 'Post Capitalism' Iwanami Shoten, 2015(In Japanese)

3 Article 3, Clause 3: 'The Union shall establish an internal market. It shall work for the sustainable development of Europe based on balanced economic growth and price stability, a highly competitive social market economy, aiming at full employment and social progress, and a high level of protection and improvement of environmental quality.'

4 Article 37: 'A high level of environmental protection and the improvement of environmental quality must be integrated into the policies of the Union and ensured in accordance with the principle of sustainable development.'

5 For example, the German Constitution (Basic Law for the Federal Republic of Germany) Art.14 [Property - Inheritance Expropriation] states, '(1) Property and the right of inheritance shall be guaranteed. Their content and limits shall be defined by the laws.' The Constitution of Japan regulates property rights in the same way in Article 29: 'The right to own or to hold property is inviolable. Property rights shall be defined by law, in conformity with the public welfare. Private property may be taken for public use upon just compensation therefor.'

6 See di Fabio, Udo (1999), Der Ausstieg aus der wirtschaftlichen Nutzung der Kernenergie, Recht - Technik - Wirtschaft Bd. 79. Ossenbühl, Fritz (1999), 'Verfassungsrechtliche Fragen eines Ausstieges aus der friedlichen Nutzung der Kernenergie' Archiv für öffentliches Recht 124, p.1ff. Schmidt-Preuß (1999), Rechtsgutachterliche Stellungnahme zum Referentenentwurf eines '100-Tage-Gesetzes' zur Änderung des Atomgesetzes v. 14. 11. 1998

See Koch, Hans-Joachim (2000), 'Der Atomausstieg und der verfassungsrechtliche Schutz des Eigentums', Neue Juristen Wochenschrift (NJW), p.1529 ff. Roller, Gerhard (1998) 'Eigentumsund entschädigungsrechtliche Fragen einer Beendigung der Kernenergieentzug', Roßnagel/Roller, Die Beendigung der Kernenergienutzung durch Gesetz., Denninger, Erhard (1999), Verfassungsrechtliche Fragen des Ausstiegs aus der Nutzung der Kernenergie zur Stromerzeugung

8 On the history of legal institution of agricultural land in Japan, see Kurumisawa, Yoshiki, 'Nouchi wo mamoru toha douiukotoka? (What does it mean to maintain agricultural land?)' Nousangyosonbunka Kyoukai, 2016. Kurumisawa,Yoshiki, 'Geschichtliche Entwicklung und aktuelle Probleme der rechtlichen Regulierung des landwirtschaftlichen Grundstückverkehrs in Japan', Jahrbuch des Agrarrechts X, Göttingen, Nomos, pp. 239-249, 2011

9 Rolf Knieper, Juristische Zusammenarbeit: Universalität und Kontext [Judicial cooperation: universality and context] (Wiesbaden: GTZ, 2004); Knieper, Rechtsreformen entlang der Seidenstraße [Legal reform along the Silk Road] (Berlin: BWV, 2006) 